\title{
Suppression of Monosodium Glutamate-Induced Acute Kidney Injury and Renal Ultrastructural Damage in Rats by Vitamin E
}

\author{
Supresión de Lesiones Renales Agudas Inducidas por Glutamato Monosódico \\ y Daño Ultraestructural Renal en Ratas por Vitamina $E$
}

\author{
Refaat A. Eid ${ }^{1}$; Mohammad Dallak²; Mubarak Al-Shraim ${ }^{1}$; Mohamed Abd Ellatif ${ }^{3,4}$; \\ Rihab Al-Ani'; Samaa S. Kamar ${ }^{6}$; Sally Negm ${ }^{7} \&$ Mohamed A. Haidara ${ }^{2,8}$
}

\begin{abstract}
EID, R. A.; DALLAK, M.; AL-SHRAIM, M.; ELLATIF, M. A.; AL-ANI, R.; KAMAR, S. S.; NEGM, S. \& HAIDARA, M. A. Suppression of monosodium glutamate-induced acute kidney injury and renal ultrastructural damage in rats by vitamin E. Int. J. Morphol., 37(4):1335-1341, 2019.
\end{abstract}

SUMMARY: Food additives and flavour enhancers used in the food industry are potential health risks. We tested the hypothesis that the food additive and flavour enhancer, monosodium glutamate (MSG), which is the sodium salt of glutamic acid can induce ultrastructural alterations to the kidney, and the antioxidant vitamin E can protect against acute kidney injuries induced by a toxic dose of MSG in a rat model of the disease. The model group of rats received a daily dose of MSG (4 gm/ $\mathrm{kg}$ ) for 7 days, whereas the protective groups were either received a $100 \mathrm{mg} / \mathrm{kg}$ vitamin E plus MSG or $300 \mathrm{mg} / \mathrm{kg}$ vitamin E plus MSG for 7 days. Rats were then sacrificed on day 8. Transmission and light microscopy images revealed substantial kidney damage induced by MSG in the model group as demonstrated by degenerated epithelial cells with Pyknotic nuclei, swollen mitochondria, damaged brush margins, dilated tubules, and widening of Bowman's space with shrinkage and deformity of some glomeruli. Treatment of the model group with vitamin E showed a substantial protection of kidney tissue and renal ultrastructure by $300 \mathrm{mg} / \mathrm{kg}$ vitamin E compared to a partial protection by $100 \mathrm{mg} / \mathrm{kg}$ vitamin E. In addition, MSG significantly $(\mathrm{p}<0.05)$ increased serum levels of urea and creatinine, which were significantly $(\mathrm{p}<0.05)$ decreased with vitamin E. However, for serum creatinine, high doses of vitamin E (300 mg/kg) were more effective than lower doses (100 mg/kg) of vitamin $\mathrm{E}$. These results indicate that vitamin $\mathrm{E}$ at $300 \mathrm{mg} / \mathrm{kg}$ effectively protects against MSG-induced acute kidney injury in rats.

KEY WORDS: Acute kidney injury; Kidney ultrastructure; Monosodium glutamate; Vitamin E; Rat model.

\section{INTRODUCTION}

MSG and other certain food additives like sodium benzoate, nitrites, and nitrates are potential health risks like cardiovascular disease, toxic to the nervous system and liver, diarrhoea and digestive disturbance, depression and mood swing, headaches and dizziness, allergic reactions, and carcinogens (Eweka et al., 2011; Shimada et al., 2013). The estimate average daily MSG intake per person in the United States is $0.2-0.5 \mathrm{~g}$ and $1.6 \mathrm{~g}$ in Korea (Geha et al., 2000). Administration of two different doses of MSG (4 and $8 \mathrm{mg} /$ $\mathrm{g}$ body weight) to mice for seven days caused a significant increase in levels of oxidative stress (MDA) and decreased in antioxidants (SOD, GSH, and GPx) in cardiac tissues (Singh \& Ahluwalia, 2012).

The liver and kidney are affected by toxic doses of MSG that cause inflammation, oxidative stress, oxidative kidney damage, and hepatocellular damage (Onyema et al., 2006; Wang et al., 2015). It was reported that MSG-induced obesity-related inflammation in livers of rats, as demonstrated by a significant increase in the gene expression of TNF-a and IL-6, and increase in biomarkers of liver injury such as ALT and AST (Wang et al.). Also, administration of

\footnotetext{
${ }^{1}$ Department of Pathology, College of Medicine, King Khalid University, Abha 61421, Saudi Arabia.

${ }^{2}$ Department of Physiology, College of Medicine, King Khalid University, Abha 6142, Saudi Arabia.

${ }^{3}$ Department of Clinical Biochemistry, College of Medicine, King Khalid University, Abha 61421, Saudi Arabia.

${ }^{4}$ Department of Medical Biochemistry, College of Medicine, Mansoura University, Mansoura, Egypt.

${ }^{5}$ Department of Microbiology, College of Medicine, King Khalid University, Abha 61421.

${ }^{6}$ Department of Medical Histology, Kasr Al-Aini Faculty of Medicine, Cairo University, Cairo, Egypt.

${ }^{7}$ Microbiology, College of Applied Medical Sciences, Mahail Campus, King Khalid University, Abha 61421, Saudi Arabia.

${ }^{8}$ Department of Physiology, Kasr Al-Aini Faculty of Medicine, Cairo University, Cairo, Egypt. Saudi Arabia.

FUNDING : This work was supported by King Khalid University grant number KKU-Project No. R.G.P - 161- 39.
} 
EID, R. A.; DALLAK, M.; AL-SHRAIM, M.; ELLATIF, M. A.; AL-ANI, R.; KAMAR, S. S.; NEGM, S. \& HAIDARA, M. A. Suppression of monosodium glutamate-induced acute kidney injury and renal ultrastructural damage in rats by vitamin E. Int. J. Morphol., 37(4):1335-1341, 2019.

low dose of MSG $(0.6 \mathrm{mg} / \mathrm{g}$ body weight) to rats for ten days induced levels of lipid peroxidation and ALT and AST; and decreased the levels of the antioxidant GSH (Onyema et al.). Furthermore, intraperitoneal injection of MSG into rats markedly increased kidney biomarkers of oxidative stress and decreased antioxidants (Farombi \& Onyema, 2006).

The antioxidant and anti-inflammatory effects of vitamin E have been documented (Ramanathan et al., 2018; Rizvi et al., 2014). Vitamin E is reported to slow kidney failure owing to oxidative stress (Fryer, 1997), reduces high blood pressure in cases of kidney failure (Tian et al., 2005), and prevents contrast medium-induced acute kidney injury (Cho et al., 2017). Also, vitamin $\mathrm{E}$ is reported to ameliorate several types of liver diseases in patients with non-alcoholic fatty liver disease (NAFLD), non-alcoholic steatohepatitis (NASH), hepatic fibrosis, inflammation and hepatocellular ballooning (Sanyal et al., 2010; Sato et al., 2015). Additionally, vitamin $\mathrm{E}$ has been used in animal models of many liver diseases to significantly attenuate NAFLD (Oliveira et al., 2003), NASH (Zamin et al., 2010), CCl4 induced hepatic fibrosis (Tian et al., 2019), and MSGinduced oxidative stress and liver injury enzymes (Onyema et al.). However, vitamin $\mathrm{E}$ has not been used before to protect the kidney ultrastructure upon MSG intoxication in an animal model. Therefore, we speculated that vitamin $\mathrm{E}$ at high dosage might protect against MSG-induced kidney injury and kidney ultrastructural alterations in rats.

\section{MATERIAL AND METHOD}

Animals. The medical research ethical committee approved all experimental procedures at King Khalid University and according to the Guide for the Care and Use of Laboratory Animals published by the US National Institutes of Health. (NIH publication No. 85-23, revised 1996). Sprague Dawley rats $(n=18)$ weighing $170-200 \mathrm{~g}$ were used in this study. All rats were bred and housed in the research centre of King Khalid University, college of medicine (Abha, Saudi Arabia), at a temperature of $23 \pm 1{ }^{\circ} \mathrm{C}$ and a $12 \mathrm{~h}$ light: $12 \mathrm{~h}$ dark cycle. Rats had free access to tap water and fed standard laboratory chow during the acclimatization period.

Experimental design. After a one week adaptation, the rats were randomly divided into 4 groups $(n=6$; each) and were distributed in their corresponding cages and classified as follows: (1) Control group: rats received normal saline daily for 7 days; (2) MSG intoxicated group (Model group): rats received a daily dose of MSG ( $4 \mathrm{~g} / \mathrm{kg}$, orally) for 7 days (Singh \& Ahluwalia); (3) MSG+Vit E100 group: rats received MSG as above plus $100 \mathrm{mg} / \mathrm{kg}$ vitamin E (orally) for 7 consecutive days; and (4) MSG+Vit E300 group: rats received MSG as above plus $300 \mathrm{mg} / \mathrm{kg}$ vitamin $\mathrm{E}$ for 7 consecutive days. All animals were sacrificed on day 8 .

Blood samples. At the end of the experimental period, blood samples were collected by cardiac puncture under anaesthesia (sodium thiopentone at $40 \mathrm{mg} / \mathrm{kg}$ body weight) after an overnight fast of 12 hours. These blood samples were collected without anticoagulant, left for $10 \mathrm{~min}$, then centrifuged for $10 \mathrm{~min}$ at $4000 \mathrm{r} / \mathrm{min}$ to obtain serum, which was stored at minus $20^{\circ} \mathrm{C}$ until further biochemical analysis.

Determination of serum levels of urea and creatinine. At day 8 , animals were sacrificed, and kidney function was evaluated by assessing serum levels of urea and creatinine using colourimetric methods according to manufacturer's instruction (BioAssay System, USA).

Histological examination. As we previously reported (AlHashem et al., 2019), kidney specimens were immediately fixed in $10 \%$ formal saline for 24 hours. Paraffin blocks were prepared, and $5 \mathrm{~mm}$ thick sections were subjected to hematoxylin and eosin (H\&E) stain to elucidate the status of kidney architecture and the structural changes.

Transmission Electron Microscopy (TEM). As we previously reported (Al-Hashem et al.), Small pieces of kidney tissues were removed and immediately fixed in 2.5 $\%$ glutaraldehyde for 24 hours and washed with phosphate buffer (0.1 M, PH 7.4). Post-fixation was made in $1 \%$ osmium tetroxide buffered to $\mathrm{PH} 7.4$ with $0.1 \mathrm{M}$ phosphate buffer at $4{ }^{\circ} \mathrm{C}$ for $1-2$ hours. The samples washed in phosphate buffer to remove excess fixative, dehydrated through ascending grades of ethanol followed by clearing in propylene oxide. The specimens were embedded in Araldite 502, to form gelatin capsules. Polymerization was obtained by placing the capsules at $60{ }^{\circ} \mathrm{C}$. Semi-thin sections ( 1 $\mathrm{mm}$ thick) were stained with toluidine blue for orientation and observation. Ultra-thin sections (100 $\mathrm{nm}$ ) were prepared using ultra-microtome and picked up on uncoated copper grids. Following double staining with uranyl acetate and lead citrate, three to five random micrographs for each section were examined and photographed using a JEM-1011-JEOL transmission electron microscope, Japan, at $80 \mathrm{Kv}$.

Statistical analysis. The data were expressed as mean \pm standard deviation (SD). Data were processed and analyzed using the SPSS version 10.0 (SPSS, Inc., Chicago, Ill., USA). One-way ANOVA was done followed by Tukey's post hoc test. Pearson correlation statistical analysis was done for the detection of a probable significance between two different parameters. Results were considered significant if $\mathrm{p} \leq 0.05$. 


\section{RESULTS}

Induction of acute kidney injury in rats by MSG. Acute kidney injury was induced in the model group of rats by a toxic dose of MSG ( $4 \mathrm{~g} / \mathrm{kg}$ body weight), which was confirmed after 8 days as shown by high blood levels in a
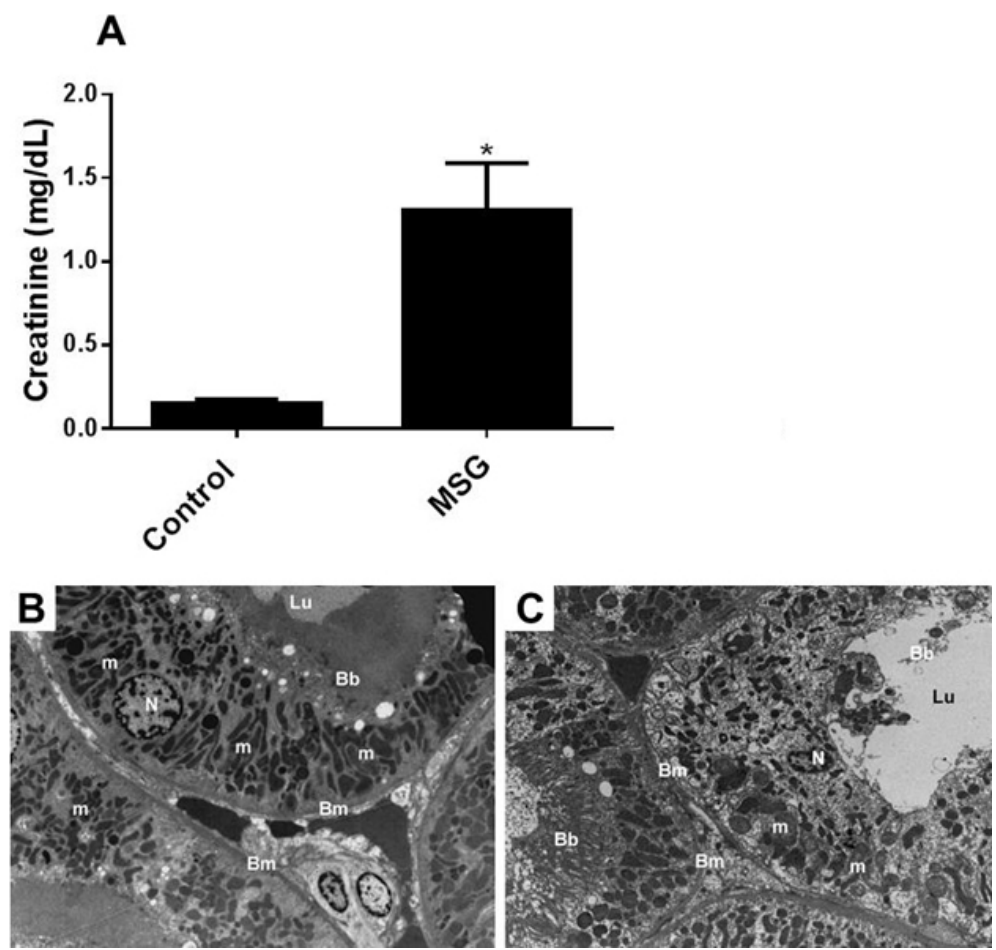

Fig. 1. Induction of acute kidney injury in rats by MSG. Blood levels of creatinine (A) were measured at the end of the experiment, after 8 days in the model group (MSG) compared to the control group of rats ( $n=6$ for each group). Results represent the mean $( \pm \mathrm{SD})$, and experiments were performed in triplicate. $* \mathrm{p}<0.05$ versus control. TEM images (B and C, x2500) of harvested tissues obtained from the kidney of the model group (C) compared to the control group (B) are visualized using transmission electron microscopy. Abbreviations: $\mathrm{N}$, nucleus; $\mathrm{m}$, mitochondria; $\mathrm{Bm}$, cell basement membrane; $\mathrm{Bb}$, brush margins, Lu, tubular lumen. biomarker of kidney injury and profound damage to kidney cells (Fig. 1). MSG-induced nephrotoxicity which caused about a seven-fold increase in serum creatinine (Fig. 1A) and TEM images of kidney sections of the proximal convoluted tubules (Figs. 1B and 1C) and renal corpuscles (data not shown) confirmed kidney injury and abnormal changes to renal ultrastructure. Kidney sections from the control group (Fig. 1B) revealed normal epithelial cells surrounded by a basement membrane. Each epithelial cell consists of a normal nucleus, mitochondria, and brush margins. Whereas, images at similar magnification prepared from kidney sections of the MSG rats of (Fig. 1C) show degenerate epithelial cells with Pyknotic nuclei, swollen mitochondria, and damaged brush margins.

Vitamin E reduces MSG-induced biomarkers of kidney injury. At day 8, animals were sacrificed, and kidney function was evaluated by assessing serum levels of urea and creatinine. High blood urea and creatinine are well known to be involved in the pathology of acute kidney injury in animal models and humans (Kohansal et al., 2019; Zhang et al., 2019). We investigated the level of inhibition of urea and creatinine in blood samples upon treating rats with two doses of vitamin E; 100 and $300 \mathrm{mg} /$ $\mathrm{kg}$ for 7 days using our protective approach. Compared to the model group, a significant $(\mathrm{p}<0.05)$ inhibition of urea and creatinine (Figs. 2A and 2B) by vitamin E were observed. However, blood levels urea were not significantly different ( $p>0.05)$ between MSG+Vit E100 and MSG+Vit E300 rat groups. Whereas, only vitamin $\mathrm{E}$ at $300 \mathrm{mg} / \mathrm{kg}$ was able to bring down serum creatinine to levels comparable to the control group (Fig. 2).
A

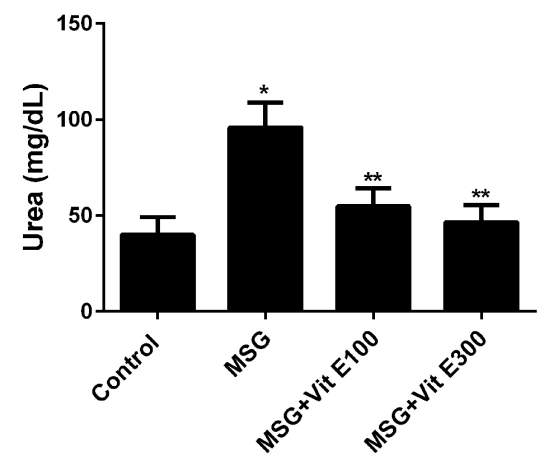

B

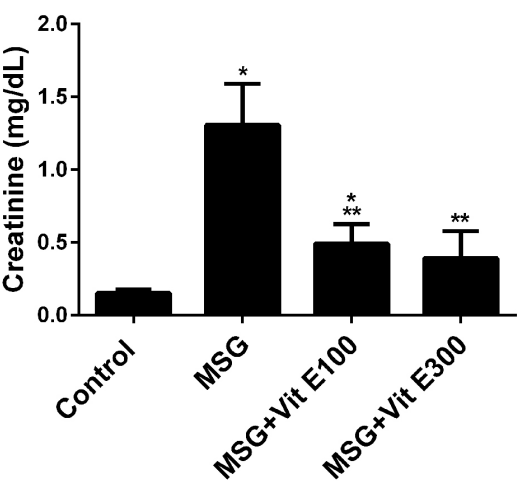

Fig. 2. Vitamin E protects against MSG-induced biomarkers of kidney injury. Serum levels of urea (A) and creatinine (B) were measured at the end of the experiment, after 8 days in 4 groups of rats; Control group, MSG group, $\mathrm{MSG}+100 \mathrm{mg} / \mathrm{kg}$ vitamin $\mathrm{E}$ (MSG+Vit E100) group, and $\mathrm{MSG}+300 \mathrm{mg} / \mathrm{kg}$ vitamin $\mathrm{E}$ (MSG+Vit E300) group. Results represent the mean $( \pm S D) ; n=6$ for each group. Experiments were performed in triplicate. $* \mathrm{p}<0.05$ versus control, $* * p<0.05$ versus MSG. 
EID, R. A.; DALLAK, M.; AL-SHRAIM, M.; ELLATIF, M. A.; AL-ANI, R.; KAMAR, S. S.; NEGM, S. \& HAIDARA, M. A. Suppression of monosodium glutamate-induced acute kidney injury and renal ultrastructural damage in rats by vitamin E. Int. J. Morphol., 37(4):1335-1341, 2019.

Vitamin E protects kidney tissue against MSGinduced acute injury. Harvested kidney tissues from all rat groups were examined by light microscopy after staining with H\&E. Compared to normal histological structure of renal tubules and renal corpuscles in the control group (Fig. 3A), MSG caused dilated tubules (arrowheads), widening of (Glomerular space) (curved arrows) and deformed glomeruli (arrows) (Fig. 3B). Administration of low doses of vitamin $\mathrm{E}(100 \mathrm{mg} / \mathrm{kg})$ ameliorated the nephrotoxic effect of MSG. However, some dilated tubule (arrowhead) were still seen (Fig. 3C). On the other hand, giving high doses of vitamin $\mathrm{E}(300 \mathrm{mg} / \mathrm{kg})$ preserved the normal structure of the renal tubules and renal corpuscles comparable to the control group (Fig. 3D).

Vitamin E protects kidney ultrastructural damage induced by MSG. We assessed the effect of daily ingestion of two doses of vitamin E into two groups of rats; 100 and
$300 \mathrm{mg} / \mathrm{kg}$ given at the same time with MSG for 7 days in order to determine whether vitamin E can protect the ultrastructure of kidney against damage induced by MSG. Representative TEM images of kidney sections at magnification (x6000) display the ultrastructure of the proximal convoluted tubules prepared from the control animal group (Fig. 4A) that show normal renal ultrastructure and normal infolding cell membranes, the model group (Fig. 4B), which displays alterations to the ultrastructure similar to (Fig. 1C) plus damaged infolding membranes (arrow). The low doses vitamin E treated group (Fig. 4C) showing normal convoluted tubule with partial changes in their epithelial cells. They surrounded by normal basement membranes $(\mathrm{Bm})$. Each epithelial cell consists of a normal nucleus $(\mathrm{N})$, mitochondria $(\mathrm{m})$ and brush margins $(\mathrm{Bb})$. Infolding membranes (arrow) are also seen. Whereas, the high doses vitamin E treated group (Fig. 4D) revealed normal renal ultrastructure comparable to the control group.
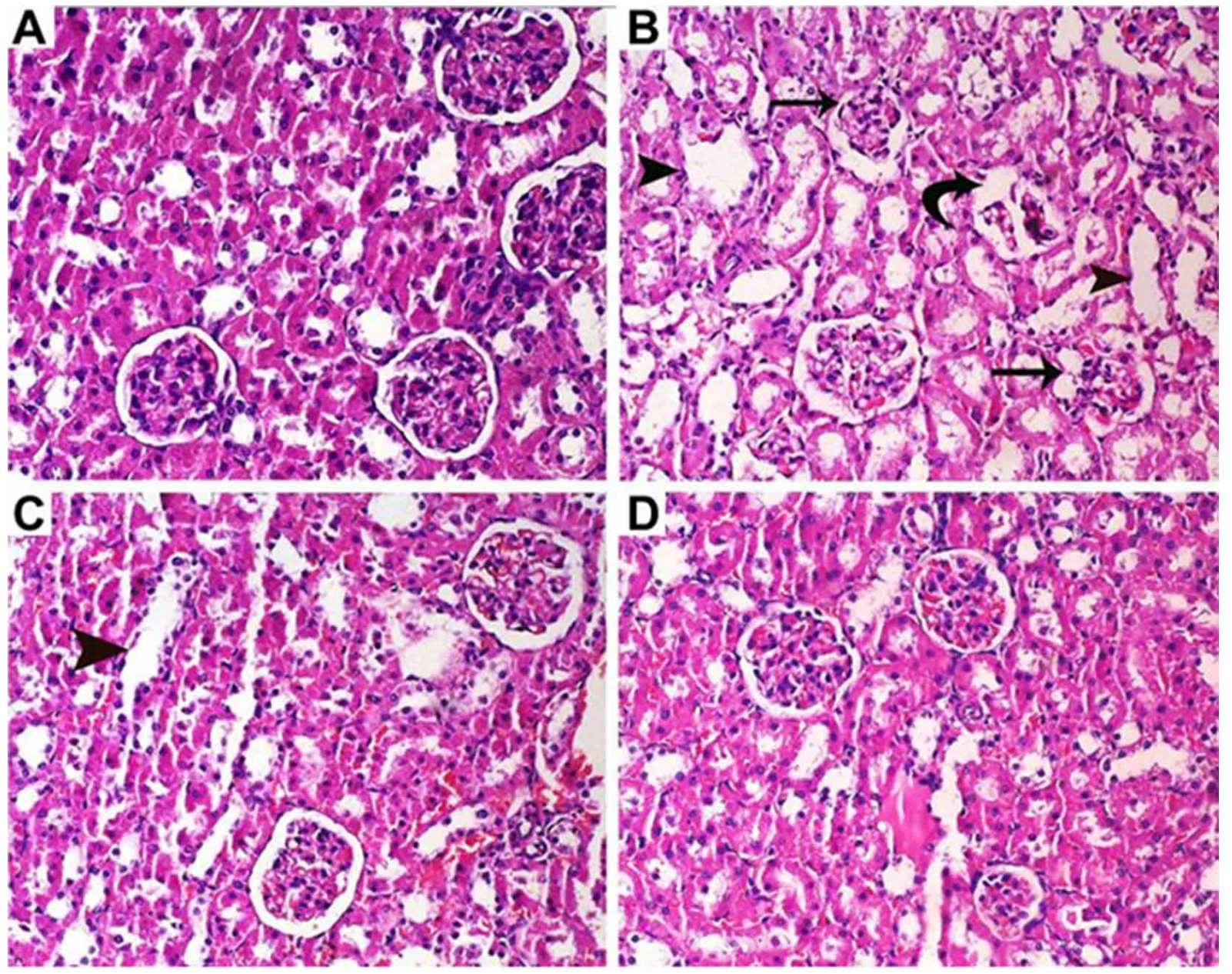

Fig. 3. Vitamin E protects kidney architecture against acute injury induced by MSG. H\&E stained images (x200) of harvested tissues obtained after 8 days from the kidney of the control group (A), MSG group (B), MSG+100 mg/kg vitamin E (MSG+Vit E100) group (C), and MSG+300 mg/kg vitamin E (MSG+ Vit E300) group (D). Note that arrowheads point to dilated tubules, arrows point to deformed glomeruli, and curved arrow points to the widening of the (Glomerular space). 

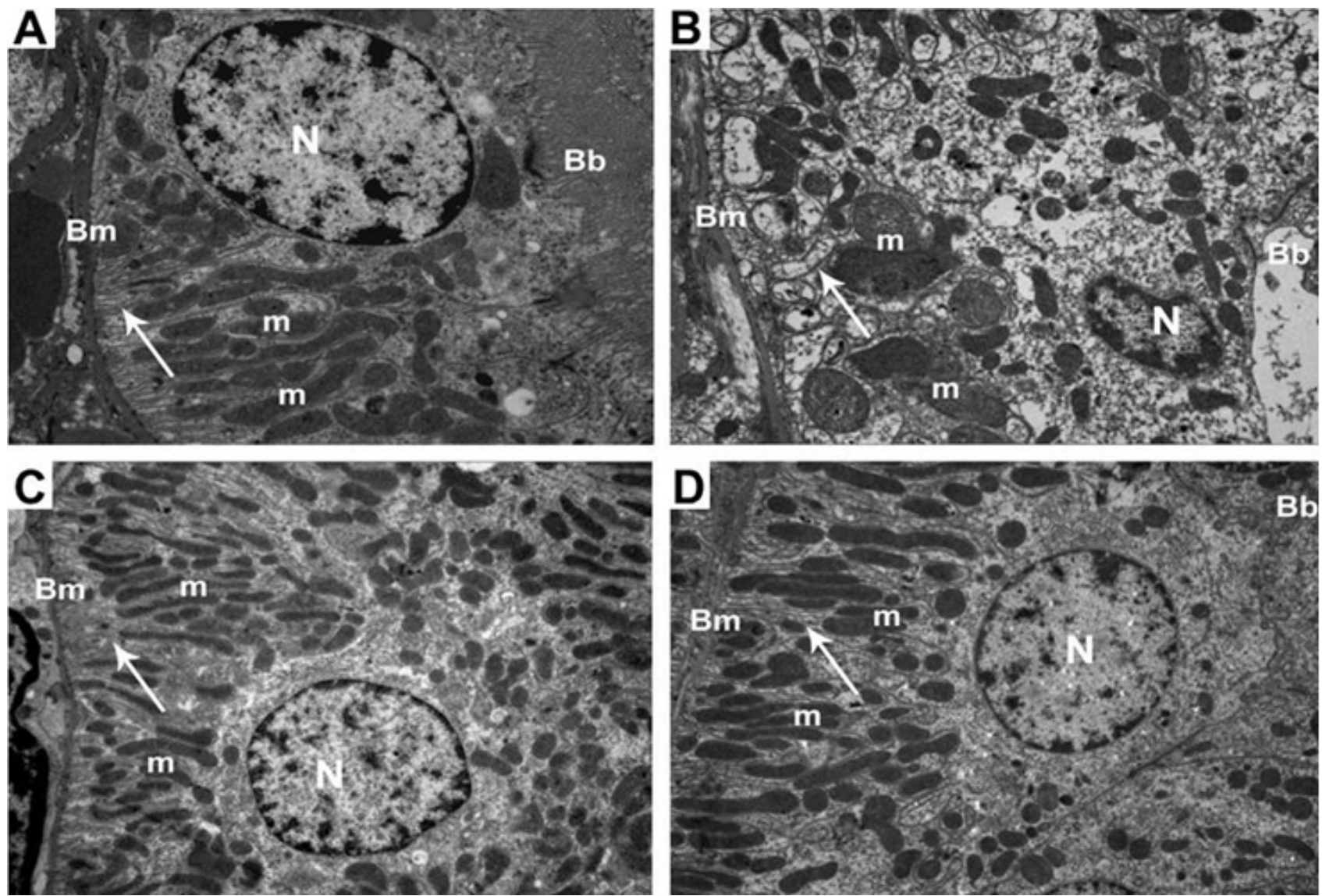

Fig. 4. Vitamin E protects against MSG-induced renal tubular ultrastructural damage in rats. TEM images (x6000) of the kidney obtained at the end of the experiment, after 8 days. (A), Control group. (B), MSG group. (C), MSG+100 mg/kg vitamin E (MSG+Vit E100) group, and (D), MSG+300 mg/kg vitamin E (MSG+Vit E300) group. Note that arrows point to infolding cell membranes. Abbreviations: N, nucleus; m, mitochondria; Bm, cell basement membrane; Bb, brush margins, Lu, tubular lumen.

\section{DISCUSSION}

The main objective of our study was to investigate the potential alterations to the kidney ultrastructure induced by toxic doses of MSG and whether vitamin $\mathrm{E}$ can inhibit both kidney tissue and cells against damage induced by MSG in a rat model of acute kidney injury. Therefore, rats were treated for 7 days with either a 100 or $300 \mathrm{mg} / \mathrm{kg}$ of vitamin E plus MSG, and the histological and biochemical parameters were examined and confirmed the beneficial effects of vitamin $\mathrm{E}$ at $300 \mathrm{mg} / \mathrm{kg}$ (Figs. 2-4). Our data support the conclusions that MSG caused intense damage to the kidney ultrastructure (Figs. 1C and 4B), tissue injury (Fig. 3B), and induced biomarkers of kidney injury, urea and creatinine (Fig. 2), which were substantially protected by vitamin $\mathrm{E}$ (Figs. 2-4). However, cell and tissue injuries were more effectively protected with a $300 \mathrm{mg} / \mathrm{kg}$ vitamin E compared to partial protection with the lower dose, $100 \mathrm{mg} / \mathrm{kg}$ vitamin E. Therefore, our results were consistent with our working hypothesis that MSG can induce kidney ultrastructural alterations, and vitamin $\mathrm{E}$ can protect against acute kidney injury induced by MSG in a rat model of the disease.

Previously published work showed that MSGinduced toxicity in renal culture cells (Leung et al., 2008), kidney damage (Sharma, 2015), alteration in glomerular and tubular histology, increase in urea and creatinine, and kidney infiltration of inflammatory cells (Contini et al., 2017). Therefore, our data that point to MSG caused high blood urea and creatinine and kidney tissue damage, and inflammatory cell infiltration are in agreement with the above findings. However, our TEM data are the first report on MSG-induced kidney ultrastructural alterations.

Our data that point to the adequate protection of vitamin $\mathrm{E}$ against (4 g/kg) MSG-induced acute kidney injury 
for a period of 8 days, are in agreement and complement a previous report that showed vitamin E inhibited chronic kidney injury induced by giving ( $4 \mathrm{~g} / \mathrm{kg}$ ) MSG to rats over 180 days (Paul et al., 2012). Thus, our data support the conclusion that vitamin $\mathrm{E}$ at $300 \mathrm{mg} / \mathrm{kg}$ effectively protects against MSG-induced acute kidney injury in rats.

\section{ACKNOWLEDGEMENTS}

The authors would like to thank Professor Bahjat AlAni from the Department of Physiology, College of Medicine, King Khalid University for his input and help during the preparation of this manuscript.

EID, R. A.; DALLAK, M.; AL-SHRAIM, M.; ELLATIF, M. A.; AL-ANI, R.; KAMAR, S. S.; NEGM, S. \& HAIDARA, M. A. Supresión de lesiones renales agudas inducidas por glutamato monosódico y daño ultraestructural renal en ratas por vitamina $\mathrm{E}$. Int. J. Morphol., 37(4):1335-1341, 2019.

RESUMEN: Los aditivos alimentarios y los potenciadores del sabor utilizados en la industria alimentaria son riesgos potenciales para la salud. Probamos la hipótesis de que el aditivo alimentario y el potenciador del sabor, glutamato monosódico (MSG), la sal sódica del ácido glutámico, puede inducir alteraciones ultraestructurales del riñón, y que las propiedades antioxidantes de la vitamina $\mathrm{E}$, pueden proteger contra las lesiones renales inducidas por una dosis tóxica de MSG en un modelo de rata. El grupo modelo de ratas recibió una dosis diaria de MSG (4 g / kg) durante 7 días, mientras que los grupos protectores recibieron una dosis de $100 \mathrm{mg} / \mathrm{kg}$ de vitamina E más MSG o $300 \mathrm{mg} / \mathrm{kg}$ de vitamina E más MSG durante 7 días. Las ratas se sacrificaron el día 8. Las imágenes de microscopía óptica y de transmisión revelaron un daño renal sustancial inducido por el MSG en el grupo modelo, como lo demuestran las células epiteliales degeneradas con núcleos picnóticos, mitocondrias hinchadas, bordes dañados, túbulos dilatados y ensanchamiento del espacio de Bowman, además de la deformidad de algunos glomérulos. El tratamiento del grupo modelo con vitamina E mostró una protección sustancial del tejido renal y la ultraestructura renal de $300 \mathrm{mg} / \mathrm{kg}$ de vitamina $\mathrm{E}$ en comparación con una protección parcial de 100 mg / kg de vitamina E. Además, el MSG aumentó significativamente $(\mathrm{p}<0,05)$ en el suero los niveles de urea y creatinina, disminuyeron significativamente $(\mathrm{p}<0,05)$ con la vitamina $\mathrm{E}$. Sin embargo, para la creatinina sérica, las dosis altas de vitamina E $(300 \mathrm{mg} / \mathrm{kg}$ ) fueron más efectivas que las dosis más bajas $(100 \mathrm{mg} / \mathrm{kg})$ de vitamina E. Estos resultados indican que la vitamina E a $300 \mathrm{mg} /$ $\mathrm{kg}$ protege eficazmente contra la lesión renal aguda inducida por MSG en ratas.

PALABRAS CLAVE: Lesión renal aguda; Ultraestructura renal; Glutamato monosódico; Vitamina $\mathrm{E}$; Modelo de rata.

\section{REFERENCES}

Al-Hashem, F.; Al-Humayed, S.; Amin, S. N.; Kamar, S. S.; Mansy, S. S.; Hassan, S.; Abdel-Salam, L. O.; Ellatif, M. A.; Alfaifi, M.; Haidara, M. A.; et al. Metformin inhibits mTOR-HIF-1a axis and profibrogenic and inflammatory biomarkers in thioacetamideinduced hepatic tissue alterations. J. Cell Physiol., 234(6):9328-37, 2019.

Cho, M. H.; Kim, S. N.; Park, H. W.; Chung, S. \& Kim, K. S. Could vitamin E Prevent contrast-induced acute kidney injury? A systematic review and meta-analysis. J. Korean Med. Sci., 32(9): 1468-73, 2017.

Contini, M. D. C.; Fabro, A.; Millen, N.; Benmelej, A. \& Mahieu, S. Adverse effects in kidney function, antioxidant systems and histopathology in rats receiving monosodium glutamate diet. Exp. Toxicol. Pathol., 69(7):547-56, 2017.

Eweka, A. O.; Igbigbi, P. S. \& Ucheya, R. E. Histochemical studies of the effects of monosodium glutamate on the liver of adult Wistar rats. Ann. Med. Health Sci. Res., 1(1): 21-9, 2011.

Farombi, E. O. \& Onyema, O. O. Monosodium glutamate-induced oxidative damage and genotoxicity in the rat: modulatory role of vitamin C, vitamin E and quercetin. Hum. Exp. Toxicol., 25(5):2519, 2006.

Fryer, M. J. Vitamin E may slow kidney failure owing to oxidative stress. Redox Rep., 3(5-6):259-61, 1997.

Geha, R. S.; Beiser, A.; Ren, C.; Patterson, R.; Greenberger, P. A.; Grammer, L. C.; Ditto, A. M.; Harris, K. E.; Shaughnessy, M. A.; Yarnold, P. R.; et al. Review of alleged reaction to monosodium glutamate and outcome of a multicenter double-blind placebocontrolled study. J. Nutr., 130(4S Suppl.):1058S-62S, 2000.

Kohansal, P.; Rajai, N.; Dehpour, A. R.; Rashidian, A. \& Shafaroodi, $\mathrm{H}$. The protective effect of acute pantoprazole pretreatment on renal ischemia/reperfusion injury in rats. Fundam. Clin. Pharmacol., 33(4):405-11, 2019.

Leung, J. C.; Ragland, N.; Marphis, T. \& Silverstein, D. M. NMDA agonists and antagonists induce renal culture cell toxicity. Med. Chem., 4(6):565-71, 2008.

Oliveira, C. P.; Gayotto, L. C.; Tatai, C.; Della Nina, B. I.; Lima, E. S.; Abdalla, D. S.; Lopasso, F. P.; Laurindo, F. R. \& Carrilho, F. J. Vitamin $\mathrm{C}$ and vitamin $\mathrm{E}$ in prevention of Nonalcoholic Fatty Liver Disease (NAFLD) in choline deficient diet fed rats. Nutr. J., 2:9, 2003.

Onyema, O. O.; Farombi, E. O.; Emerole, G. O.; Ukoha, A. I. \& Onyeze, G. O. Effect of vitamin E on monosodium glutamate induced hepatotoxicity and oxidative stress in rats. Indian J. Biochem. Biophys., 43(1):20-4, 2006.

Paul, M. V.; Abhilash, M.; Varghese, M. V.; Alex, M. \& Nair, R. H. Protective effects of a-tocopherol against oxidative stress related to nephrotoxicity by monosodium glutamate in rats. Toxicol. Mech. Methods, 22(8):625-30, 2012.

Ramanathan, N.; Tan, E.; Loh, L. J.; Soh, B. S. \& Yap, W. N. Tocotrienol is a cardioprotective agent against ageing-associated cardiovascular disease and its associated morbidities. Nutr. Metab. (Lond.), 15:6, 2018.

Rizvi, S.; Raza, S. T.; Ahmed, F.; Ahmad, A.; Abbas, S. \& Mahdi, F. The role of vitamin e in human health and some diseases. Sultan Qaboos Univ. Med. J., 14(2):e157-65, 2014.

Sanyal, A. J.; Chalasani, N.; Kowdley, K. V.; McCullough, A.; Diehl, A. M.; Bass, N. M.; Neuschwander-Tetri, B. A.; Lavine, J. E.; Tonascia, J.; Unalp, A.; et al. Pioglitazone, vitamin E, or placebo for nonalcoholic steatohepatitis. N. Engl. J. Med., 362(18):1675-85, 2010. 
Sato, K.; Gosho, M.; Yamamoto, T.; Kobayashi, Y.; Ishii, N.; Ohashi, T.; Nakade, Y.; Ito, K.; Fukuzawa, Y. \& Yoneda, M. Vitamin E has a beneficial effect on nonalcoholic fatty liver disease: a meta-analysis of randomized controlled trials. Nutrition, 31(7-8):923-30, 2015.

Sharma, A. Monosodium glutamate-induced oxidative kidney damage and possible mechanisms: a mini-review. J. Biomed. Sci., 22:93, 2015.

Shimada, A.; Cairns, B. E.; Vad, N.; Ulriksen, K.; Pedersen, A. M.; Svensson, P. \& Baad-Hansen, L. Headache and mechanical sensitization of human pericranial muscles after repeated intake of monosodium glutamate (MSG). J. Headache Pain, 14:2, 2013.

Singh, K. \& Ahluwalia, P. Effect of monosodium glutamate on lipid peroxidation and certain antioxidant enzymes in cardiac tissue of alcoholic adult male mice. J. Cardiovasc. Dis. Res., 3(1):12-8, 2012.

Tian, H.; Liu, L.; Li, Z.; Liu, W.; Sun, Z.; Xu, Y.; Wang, S.; Liang, C.; Hai, Y.; Feng, Q.; et al. Chinese medicine CGA formula ameliorates liver fibrosis induced by carbon tetrachloride involving inhibition of hepatic apoptosis in rats. J. Ethnopharmacol., 232:227-35, 2019.

Tian, N.; Thrasher, K. D.; Gundy, P. D.; Hughson, M. D. \& Manning, R. D. Jr. Antioxidant treatment prevents renal damage and dysfunction and reduces arterial pressure in salt-sensitive hypertension. Hypertension, 45(5):934-9, 2005.

Wang, W. F.; Li, S. M.; Ren, G. P.; Zheng, W.; Lu, Y. J.; Yu, Y. H.; Xu, W. J.; Li, T. H.; Zhou, L. H.; Liu, Y.; et al. Recombinant murine fibroblast growth factor 21 ameliorates obesity-related inflammation in monosodium glutamate-induced obesity rats. Endocrine, 49:11929, 2015.

Zamin, I. Jr.; Mattos, A. A.; Mattos, A. Z.; Coral, G.; Santos, D. \& Rhoden, C. The vitamin E reduces liver lipoperoxidation and fibrosis in a model of nonalcoholic steatohepatitis. Arq. Gastroenterol., 47(1):86-92, 2010

Zhang, M.; Chen, Y.; Yang, M. J.; Fan, X. R.; Xie, H.; Zhang, L.; Nie, Y. S. \& Yan, M. Celastrol attenuates renal injury in diabetic rats via MAPK/NF-kB pathway. Phytother. Res., 33(4):1191-8, 2019.

\author{
Corresponding author: \\ Dr Refaat A. Eid \\ Department of Pathology \\ College of Medicine \\ King Khalid University \\ Abha 61421 \\ SAUDI ARABIA
}

E-mail: refaat_eid@yahoo.com

Received: 08-03-2019

Accepted: 21-06-2019 